\title{
TEACHING AND COACHING SKILLS
}

\author{
Marjana Penca Palčič ${ }^{1}$ \\ OŠ Šentjernej, \\ Slovenia
}

\begin{abstract}
The purpose of the article is to show how knowledge of coaching skills can help achieve the desired results in pedagogical practice faster and more efficiently. When coaching skills are known by a team of teachers, these teachers can offer each other support in personal and professional growth (collegial coaching). They do not necessarily have to be professional coaches. It is essential that the teacher acting as a coach uses specifically selected questions. These need to encourage their interlocutor to think and find their own solutions to achieve the goal. They must be open and unsuggestive. In this way, the interlocutor will come up with solutions that they would otherwise be difficult, or even impossible for $\mathrm{him} / \mathrm{her}$ to reach. Conversation, guided by coaching questions, can also help learners with the difficulties they encounter. It is important that the interlocutor wants to solve the problem, the challenge. The case study shows how to use coaching skills, especially coaching questions, in pedagogical practice
\end{abstract}

Keywords: coaching, collegial coaching, coaching questions, teacher as a motivator.

\section{Introduction}

"There is no good teaching. There are only good teachers. In other words, teaching is realized only in teachers; it does not exist on its own" (Richards, 1994, as cited in Cvetek, 2004, p. 145). I believe that the teacher is more effective in teaching if he has colleagues who provide support when he needs it. A group of five teachers from our school attended the seminar Collegial Support With the Help of Coaching Skills. Coaching is "one of the most promising approaches for promoting personal and professional development" (Rutar llc, 2014).

The objectives of the program were to promote and strengthen the culture of collegial support and good relations among teachers, to strengthen the social competences and communication skills of teachers, to contribute to greater efficiency and goal orientation of teachers. During the program implementation, the participants adopted basic coaching skills. The training was led by Zora Rutar Ilc, Brigita Žarkovič Adlešič and Blanka Tacer, who are also authors of Collegial Coaching, a manual for professional and personal development. The authors strive to spread knowledge of the approach and awareness of the importance

1 marjana.penca@guest.arnes.si 
and value of their skills in everyday life. For many who find themselves in a clutch situation, the coaching process makes it possible to help themselves or others with the "checking techniques" (Rutar Ilc, 2014).

People usually do not think about their problems, challenges, out loud. When we do that, our interlocutors quickly start giving us advice and offering solutions. They begin to talk about a similar situation that they themselves have experienced. Of course these are their solutions, not ours. "Coaching as a method of learning goes beyond that. It gives a person an opportunity to think about the challenge he is dealing with at a specific point in time. Mastering its basic skills can thus raise the level of communication throughout a collective or community. This is an approach in which you work with your interlocutor in such a way that you encourage him to explore and find the solutions that are best for him. Coaching should shake off its own assumptions and beliefs and support a colleague or client in his world, on his way of finding his own solutions" (Rutar Ilc, 2014).

After completing the training, I came to the realization that the teacher can be more successful in his work if he knows coaching skills: active listening, summarizing, mirroring and paraphrasing, feedback, creating trust, monitoring and good contact, spreading awareness and promoting response, empathy, coaching questions. I find using the latter extremely useful for professional growth. The questions must be open, clear, short, with a single negation at most (What are you not willing to give up?), content free, with research interest, without interpretations, unsuggestive, considerate, targeted (Rutar Ilc, Tacer, \& Žarkovič Adlešič, 2014).

The purpose of the case study was to determine how coaching skills can be used in pedagogical practice and what are the effects on coaching process participants.

\section{Application of coaching skills in pedagogical practice}

"Undoubtedly, the knowledge of pupils depends not only on the school system, but even more so on the teaching staff, on their diligence and ability" (Šifrer, 1963, p. 340).

Headmasters often ascribe importance of motivating students, but forget that a motivated teacher can sometimes do wonders for students. I am referring primarily to the inner motivation of a teacher who wants to grow professionally. Such a teacher is often self-empowered and does not even need the supervision of the headmaster, as he is usually quite self-critical. In any case, however, such a teacher, too, finds the encouraging words of the headmaster very meaningful and a source of additional encouragement.

Each educational process is also a communication between the student and the teacher. Lately, coaching is increasingly making its way into the economy, education, as well as numerous other areas. "Coaching is one of the most promising ways of supporting individuals and groups in personal and professional development" (Rutar llc et al., 2014, p. 8). Knowing coaching skills can help the teacher make his messages to students more encouraging. Sims $(2000$, p. 35$)$ in the book Promoting Excellence, describes a conversation about Miss Alexander. "Why was she your favorite teacher?" "She expected me to do good. She cared about me. I do not remember what she taught me, I only remember the good feelings I had in her classroom." "Do you therefore want to say that it does not matter what we have learned, but from whom 
have we learned it?" Sarah asked. "Yes, I think so. That year my grades improved. She helped me get those good grades. I simply felt nice there." "Have you attempted something risky in her classes?" Sarah asked. "I could try anything with her. I knew she would never yell at me or humiliate me, even if I made a mistake ..." I have also come to the realization myself that the teacher who knows how to listen to, encourage, guide students and tolerate their mistakes, who is genuinely interested in students' achievements and their distress, has a positive influence on the students. Knowing coaching skills helps us in communicating with students.

Coaching models help us conduct a conversation. The GROW model (Whitemore, 2009 , as cited in Rutar Ilc et al., 2014) is one of the most famous models. The abbreviation originates from the words Goal, Reality, Options, Will. In the first phase, the client specifies exactly what he wants. In the second phase, the coach encourages the client to think about the current situation. In the third phase, the coach helps the client explore alternative options. The final stage is for planning, the first action steps. The solution must come from the client. It will only work if the client invests an appropriate level of energy into it.

The SCORE model, a.k.a. Dilts's model, is also well-known (Rutar Ilc, 2014). The abbreviation comes from the words Symptom, Cause, Outcome, Resource, Effect. Firstly, we highlight the existing situation in detail. We then encourage the interlocutor to explore the causes. In the third phase we encourage the interlocutor to raise awareness, reflect on what they want to change. What follows is an awareness of resources, potentials, strategies. Finally, we help the interlocutor to get to know the desired effects.

\section{Coaching skills helpful to a teacher}

\section{Self-coaching}

Self-coaching allows us to develop a better insight into ourselves. It is easier to understand what is happening to us, what the reason is for our reaction. We are aware that things can be done better and we find the best way for us, which will lead us to change. Thus, the mistakes we make are easier to accept and repair. It helps us to get rid of the feeling of helplessness, or the feeling that we're stuck. Our attitude towards ourselves, events, which is unconstructive or even negative, can be transformed into a constructive, positive one.

In self-coaching I am always helped by questions. I ask myself wh-questions (e.g. What do I want to change? What is the current state? What can I do? What is my plan for introducing change?). The flow of thought leads me from a clearly defined goal and the current state to possibilities, and finally to "will" or the steps I will take to achieve the goal.

Such thinking always leads to a more constructive and effective self-evaluation.

\section{Supporting a colleague}

When I find myself facing challenges that I do not know how to solve, or if I want to find a better solution in the future, I turn to my colleague who provides me with support, leading me to the goal with questions, without giving advice. Our relationship is based on an alliance. Through our alliance, we learn and develop coaching skills while working on 
ourselves. In a coaching conversation, I point out the problem that has been weighing on my mind lately. The most valuable thing to me is that I think about the problemaloud. At that point in our conversation, I do not think about the role of the coach, i.e. what I would ask if I was in the role of coach, but only about my own solution to the problem to which my colleague leads me through coaching questions. It means a lot to me that he really listens to me. This way of communication makes me calm. When my colleague hears my plans, I feel an even greater need, a desire to really make my plans real. My colleague as a coach also gives me some encouraging feedback that motivates me for the first steps towards solving the problem. Of course, the support is mutual. I also offer support when my colleague asks me for it. Constructive, positive feedback works encouragingly. It is appropriate to use it in coaching when we see progress in the client, and we want to praise him, when the client wants to hear our feedback, when the client does not advance with his thoughts towards the solution and ends up in a vicious circle. Feedback can also provide a new look at the solution to the problem and can be very useful for the person in question. A teacher as a coach can give feedback when he has enough information. Feedback in coaching could be dangerous when our feedback might provide an excuse for the interlocutor not to assume responsibility and when the coach might use it to assume a level of control.

\section{Help in class}

The teacher who presents the learning material with the intention to explain and direct students to active learning may find coaching questions helpful. Similarly, coaching questions help us with problem tasks when we want to identify the problem core and create a plan for solving a problem task. Through open questions (wh-questions), students show a better understanding of learning material and real knowledge. Questions that only require recall do not provide such insight.

Allow me to provide an example.

The teacher discussed the new teaching material in the field of natural science. In doing so, he set up an introduction or a different approach to asking questions.

The lesson or the class itself was basically set up as a challenge centered on the student, that is, his knowledge, behavior, beliefs and, last but not least, the desire to discover and acquire new knowledge.

25 years ago, when the said teacher taught a lesson with the same content (the topic was: Why do we have one year?) at one of the primary schools in Ljubljana, he used, in his set of questions, mostly those that started with WHY. At that time, this form of questions was considered very strong and very appropriate in the classroom, especially in the problemoriented treatment of the learning material.

Today, after so many years, this learning material (neither the content nor the facts have changed) began to be introduced with other questions and with the knowledge he had gained in the field of coaching skills. 
All questions that once started with the word why, were now asked as other questions.

He used these questions both in determining students' knowledge, and later on the problem-based explanation of the teaching material, where he did not want to give a classic presentation of the teaching material, presenting information that would force the student to memorize facts. Instead, with skilfully asked questions, hestimulated, coaxed them ... from the already known facts, which the students knew from before or merely linked them to the current ones.

He also used questions of this kind and his skill to tackle certain beliefs, especially if they were wrong. These thought-oriented questions are dealt with at all levels of the class, both in the presentation and in the consolidation.

The findings obtained from this were encouraging, since students were not only active listeners during the self-examination of the learning material, but were primarily active in thinking and engaging in thediscussion, in the explanation, in short, in the process that was led by open wh-questions.

At the same time, the students got a more considerable feeling that they had also contributed to the explanation of the learning materialthemselves.

Understanding is increased primarily through active work during self-explanation, conversation...

Concrete examples from this class:

WHY are there 7 days in a week?

(one closed question - one answer)

The answer to this question could only be given by a student who already has considerable knowledge of this area of astronomy.

This question is broken up into several open wh-questions.

What happens to our Moon when it circles around the Earth?

What is it like?

What changes in itsappearance?

How many times does its appearance change?

(4 phases: new moon, first quarter, full moon, last quarter)

How long does the moon need to circle the Earth?

Sub-questions:

How many months are there in a year?

How many times does the Moon circle the Earth in one year?

Back to the main questions:

How many days roughly does the Moon need to travel around the Earth?

What do I get if I divide the number of days with the number of lunar phases?

What do I get if I divide 28 by 4 ?

What is the number 7 in our calendar?

What is connected to the number 7 ? 
In this way, students are led through active thinking. In doing so they use the knowledge that they already have and connect it to the currently acquired knowledge, information, and new knowledge.

The teacher subsequently found out that the knowledge and behavior acquired by students in this way was much better. Above all, it was acquired based on reason.

\section{Collegial hospitations}

The Law on the Organization and Financing of Education (Zakon o organizaciji in financiranju vzgoje in izobraževanja, 2007), in Article 49, specifies that the head teacher as a pedagogical leader should attend the educational work of teachers, monitor their work, advise and encourage professional education and training of professional staff. Collegial hospitations are increasingly being put into practice. Teachers expect collegial hospitations to lead to an exchange of experiences, help with professional dilemmas and cross-curricular integration, engagement in joint planning and analysis (Pajer Šemrl, 2005). Collegial hospitations should also be planned in advance. Tomić (Tomić, 2002) defines three steps: 1. planning in the form of a meeting where the aim of observation is set and the instrumentation is produced, 2 . observation in the classroom with data gathering, 3. feedback with the exchange of information and planning of improvements.

Pajer Šemrl (Pajer Šemrl, 2005) states that teachers are even less fond of collegial hospitations than those by headmasters, as they are not willing to share their experiences, exchange opinions, work as a team, and, above all, fear criticism. In addition, he draws attention to the problem of closing individual teachers in their classrooms and the incompatibility with the changes in modern times.

Collegial hospitations can be of great help to us teachers, because our colleague who guides us helps us to evaluate our lessons more easily and find solutions regarding what and how to improve. However, the desire for such cooperation must come from us. Kemp and Gosling (Kemp \& Gosling, 2014) have identified the following characteristics of successful mutual hospitations:

- they are based on dialogue, questioning,

- they are not intended as judgments,

- they are focused on changing and developing practice,

- they take the professional autonomy of observers and observed into account,

- they promote mutual learning.

The condition for the implementation of collegial hospitations is a secure environment based on respect. A well-conducted hospitation can benefit the teacher and the observer in their professional development. Otherwise, a kind of hostility, resentment and mistrust may develop (Wragg, 1994). I myself, in my role as a teacher, want the feedback of my colleague with whom I feel at ease and appreciate his opinion. 


\section{Team search for solutions}

Teamwork enables division of tasks, responsibilities, a greater pool of ideas, comprehensive solutions. Good communication is of great importance for teamwork. It is important that the team members trust one another, otherwise the time and energy may be inadequately used, and the information flow may be inhibited. Instead of finding common solutions, individuals will be directed towards mutual checking and protecting their own interests. Disagreement can quickly be understood as deliberate.

Mutual support of colleagues can take the form of assistance in performing or assuming work tasks, giving feedback, coaching.

When a team that understands each other wants to come up with common solutions, knowledge of coaching skills can significantly contribute to a more effective search for solutions. A conversation moderator can also be a member of the team that knows coaching skills (coaching questions). Team members need to be familiar with the coaching process and agree with it. Knowing coaching skills contributes to a more positive and productive dialogue. In teams where there is no trust and general positive climate, such a way to find solutions is not appropriate. Provided that all members of the team want change or a solution, only a professional coach can help.

\section{Help with educational issues}

The use of methods and approaches with which it is easiest to establish order does not contribute to the sustainable development of discipline and self-control. The teacher needs "a wide action repertoire that enables him to quickly and appropriately decide in complex learning situations. It is about managing diverse, especially interactive learning methods, communication models with pupils, ways of thinking and emotionally activating, motivating, disciplining, establishing cooperative relationships"(Bauer, 2000, as cited in Marentič Požarnik, 2003, p. 183).

In the case of learning and educational problems, coaching questions can help us, but students must be prepared to make changes and find solutions. The following questions are the most helpful ones:

What do you want to achieve?

When did you manage something similar?

How did you do it?

What will help you get started differently?

Who can help you with it?

With similar questions, students arrived at their own solutions for behavior change. Their solutions were completely different.

The use of coaching questions was also helpful in the overall self-evaluation of a class which was more difficult to handle. The teacher as a coach can help students develop the feeling that they have the opportunity and responsibility to make a significant contribution to a positive class climate. Every day at the end of the lesson (last five minutes) we made an evaluation with the students. We remembered above all the observance of class rules.

The key questions that helped us with self-evaluation were: 
What have we done well?

What could we have done better?

How can we achieve that?

Students only respond appropriately when they take control of their behavior and not because they want to please the teacher. The correct decisions must be internalized. Coaching questions can help them find solutions with more ease.

\section{Coaching skills helpful for students}

\section{Help with learning difficulties}

Sometimes students find it difficult to see what causes them problems with learning. The teacher can propose a conversation to the student and, if the student is ready, offers support in finding solutions that will lead to better learning outcomes.

When thinking, we help the student with the questions:

What are the things you want to be different?

Where do you have problems?

What have you tried so far?

What else can you do?

What will be the next step?

Now we write it down ... by what time (date) you intend to do this ...

\section{Dislodging negative beliefs}

Coaching questions were also a great help in tackling the negative beliefs of a second grade student about his own inability to write stories.

Where does your belief come from?

When do you not think of yourself like that?

Imagine that writing stories is not troublesome for you. What would it look like if writing wasn't a problem?

What hinders you so that it is not the way you imagine it?

Who/what can help you with this?

What will be your first step?

Juriševič (1999) says that students need to be provided with opportunities where they will also adopt, test and use constructive strategies that contribute to the formation of healthy self-esteem. The interlocutor (student) solves the problem by means of coaching questions, and at the same time adopts different views of himself.

\section{Help in solving the problems that hinder a student}

Example of a conversation with a ten-year-old fourth-grade student. With the help of coaching questions, I provided the student with support in finding her own solutions.

A (teacher): What do you want to be different? 
$B$ (student): To not forget homework.

A: How often do you happen to forget your homework?

$B:$ Quite often. Once a week.

A: When do you not have problems with forgetting?

$B$ : I did not forget homework at the beginning of the school year.

A: What was different then?

B: I do not know.

A: What could you do to not have a problem with forgetting?

B: I do not know.

A: How did it work for you then?

$B$ : I was less forgetful.

A: What do you think causes forgetfulness?

$B:$ I do not write it down.

A: How was it before, when you did it without difficulty? What helped you at that time?

B: I listened more. I used to write it down.

A: What could you do to make it different?

$B:$ I would listen again and write it down?

A: How could this be achieved?

B: By following the explanation more closely, what the homework is. I usually do not listenclosely.

A: What leads you to not listen?

$B$ : I often get distracted by something.

A: Tell me more about this.

B: I constantly grab things, I draw ... and I stop listening.

A: If I understand you correctly, this grabbing of items discourages your attention, so you do not listen anymore.

$B$ : Yes, right.

A: What then do you feel when you begin to grab things during the explanation?

$B:$ I'm restless.

A: What makes you restless?

$B$ : I cannot wait for the end of class.

A: What is it you can't wait for after class?

B: That I can get up and draw and play with my classmates.

A: What is different now compared to the beginning of the school year?

$B$ : At that time, I was also restless, but I found it easier to focus.

A: How did you do it?

B: I calmed down more easily.

A: What is happening now that makes it harder to calm down?

$B$ : I have too much work to do.

A: Can you tell me more about this?

$B:$ I have more classes, more homework, more difficult practice in music school ...

A: If I understand you correctly, do you have the feeling now that you are overburdened?

$B:$ Yes. 
A: What causes your feeling of being overburdened?

B: I do not feel like doing anything. But when I want to work, I remember what I should do and I do not know where to start. Then I prefer to do nothing.

A: What could you change?

B: I could do my homework right after lunch. The longer I wait with the homework and studying, the less I want to do anything for school.

A: What could help you not to get distracted in class?

B: If I felt that I was being anxious, I could put my hands behind the chair and try to listen as much as possible. I think it would help me.

A: Now let's write this down...

Such was the solution for this student. She said that she felt well after the conversation and that she had the feeling that she would really succeed. We later discussed the implementation of her plans. She had done it!

\section{Conclusion}

Coaching creates a relationship in which the interlocutor (in the role of a client) feels that we care about him. The headmaster can create conditions in which the teachers are willing to introduce changes in the teaching where the desire for professional growth will be accepted. The coaching process in the school allows the teacher to fully utilize his potentials. A team of teachers that offer mutual support to each other, works more easily and with greater motivation. The students respond in a similar manner. Students who feel that the teacher accepts, stimulates, directs, tolerates mistakes, helps them with their own solutions, achieve progress faster.

Coaching, however, is not to be used to solve every problem. "In short, wisdom is to know when someone benefits more from coaching, an approach that encourages the search for one's own solution, and when some other method is necessary" (Rutar Ilc, 2014).

Coaching questions should begin withwh-words. Such questions are sufficiently open and help in self-evaluation of the teacher as well as the learner (self-coaching), testing new teaching techniques, collegial hospitations, solving problems that arise at the workplace, giving encouraging feedback, conversation with students who have a problem and want to solve it. Together with my colleagues, I find that knowledge of coaching skills (especially coaching questions) helps in the educational process itself, as well as in interaction with colleagues (see Table). Conversations that follow coaching models can also help learners to work out their priorities. I am referring here to vocational guidance and gifted students who have difficulty in deciding which activities to devote their energy to when they are simply not able to do everything they are interested in. Coaching skills: active listening, good follow-up, asking strong questions (wh-questions), dislodging limiting beliefs, giving encouraging feedback, etc. are of great help in communication when we can judge if their use is sensible. It's not necessary to be a professional coach. It's about a way of thinking that helps us to look at things from a different perspective. 
Table 1: Coaching process as help for teachers and students

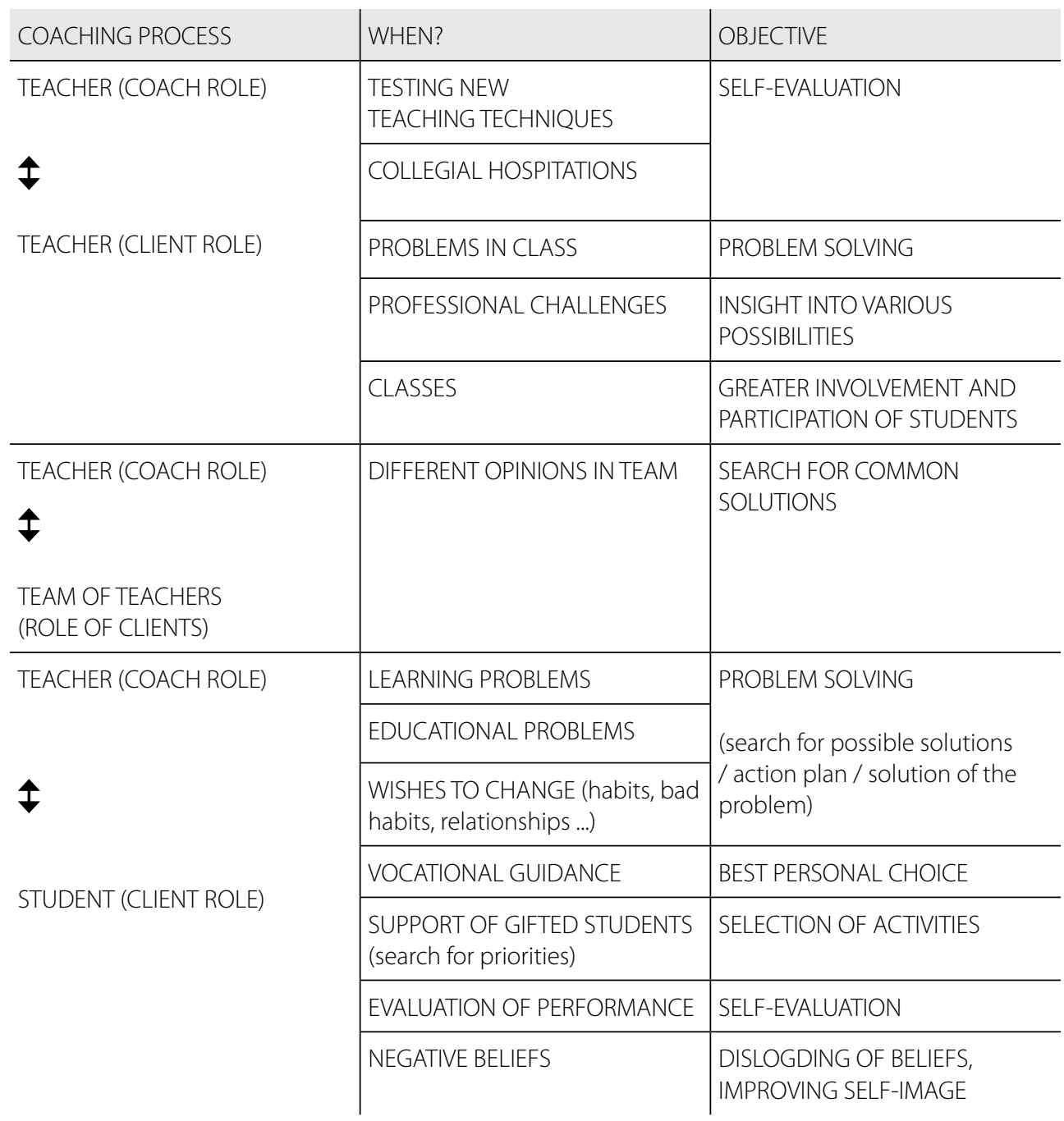

\section{References}

Cvetek, S. (2004). Kompetence v poučevanju in izobraževanju učiteljev. Sodobna pedagogika, 55 (special edition), 144-160.

Juriševič, M. (1999). Samopodoba šolskega otroka. Ljubljana: Pedagoška fakulteta.

Kemp, R., \& Gosling, D. (2014). »Peer Observation of Teaching«.Retrieved August 23, 2018 from the World Wide Web http://escalate.ac.uk/resourses/peerobservarion2/

Marentič Požarnik, B. (2003). Izobraževanje učiteljev med izzivi časa in akademsko tradicijo. In B. Krakar-Vogel (Eds.), Slovenski jezik, literatura in kultura v izobraževanju (pp. 177-185). Ljubljana: Center za slovenščino kot drugi/tuji jezik pri Oddelku za slovenistiko Filozofske fakultete. 
Pajer Šemrl, M. (2005). Pogledi učiteljev na hospitacije. Vodenje v vzgoji in izobraževanju, 1(3), 75-81.

Rutar Ilc, Z. (2014). Kolegialni coaching s preizpraševanjem iz precepa. Retrieved May 25, 2018 from the World Wide Web https://www.delo.si/zgodbe/nedeljskobranje/kolegialni-coachingspreizprasevanjem-iz-precepa.html

Rutar Ilc, Z., Tacer, B., \& Žarkovič Adlešič, B. (2014). Kolegialni coaching: priročnik za strokovni in osebni razvoj. Ljubljana: zavod Republike Slovenije za šolstvo.

Sims, P. (2000). Spodbujanje odličnosti: vsak otrok je lahko dober učenec. Tržič: Učila.

Šifrer, J. (1963). Problemi sodobne družbe. Naša šola in šolniki po desetih letih reforme. Sodobnost, $11(4), 337-343$.

Tomić, A. (2002). Spremljanje pouka. Ljubljana: Zavod RS za šolstvo.

Wragg, E. C. (1994). An introduction to classroom observation. London, New York: Routledge.

Zakon o organizaciji in financiranju vzgoje in izobraževanja. Uradni list RS, Vol. 16/2007, 23. 2. 2007. Retrieved April 28, 2018 from World Wide Web https://www.uradni-list.si/glasilo-uradni-list-rs/ vsebina/78530

Примљено: 27.08.2018.

Коригована верзија рада примљена: 10.10.2018.

Прихваћено за штампу: 05.11.2018.

\title{
НАСТАВА И ВЕШТИНЕ ПРОФЕСИОНАЛНОГ ВОЂЕЊА
}

\author{
Марјана Пенца Палчич \\ ОШ Шентјернеј, Словенија
}

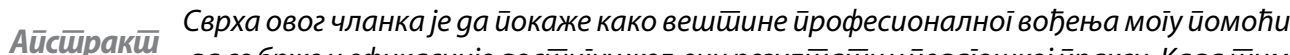

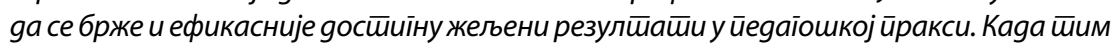

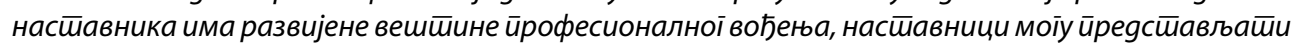
јеgан gруїом йоgршку уличном и иррофесионалном развоју (колеїијално ӣрофесионално вођене).

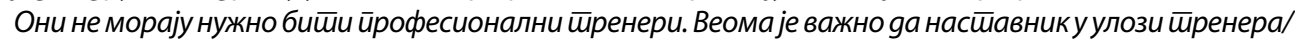

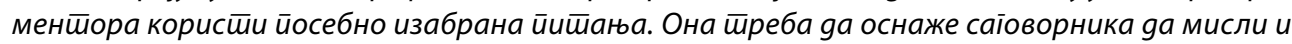

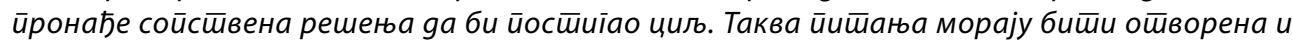
несуіесииивна. На овај начин ће насйавник саїоворник gоћи gо решења која би, без оваквої начина раgа, йронашао мноі̄о ӣеже или их уойшйе не би ӣронашао. Конверзачија која је вођена оваквим ӣитианима може йомоћи насйавницима који уче gа решавају йешкоће на које наилазе. Важно је

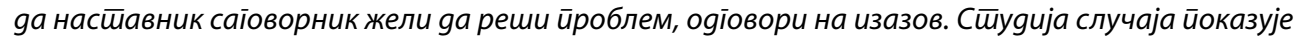

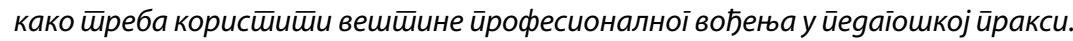

Кључнеречи: ӣрофесионално вођење, колеїијално ӣрофесионално вођење, ӣишиања у

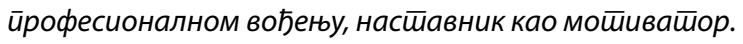




\title{
ОБУЧЕНИЕ И УМЕНИЯ ПРОФЕССИОНАЛЬНОГО РУКОВОДСТВА
}

\author{
Марьяна Пенца Палчич
}

Основная школа Шентерней, Словения

\begin{abstract}
Цель данной статьи - показать, что умения и навыки профессионального руководства Резюме могут обеспечить достижение желаемых результатов в педагогической практике более быстро и эффективно. Когда в учительском коллективе существуют развитые навыки профессионального руководства, учителя могут поддерживать друг друга в личном и профессиональном развитии (коллегиальное профессиональное руководство). При этом, учителя не обязательно должны быть профессиональными тренерами, но крайне важно, чтобы они в роли тренера использовали специально отобранные вопросы. Эти открытые и невнушительные вопросы должны помочь собеседнику думать и находить решения для достижения цели. Таким образом, учитель-собеседник приходит к решению, которое без указанного метода работы было бы гораздо сложнее или вообще не возможно найти. Собеседование, проведенное с помощью таких вопросов, может помочь учителям которые учатся решать трудности, с которыми сталкиваются. Существенно важным является желание учителя-собеседника решить проблему, ответить на вызов. Исследование показывает, как можно использовать навыки и умения профессионального руководства в педагогической практике.
\end{abstract}

Ключевые слова: профессиональноеруководство, коллегиальноепрофессиональноеруководство, вопросы в профессиональном руководстве, учитель как мотиватор. 